\title{
Nucleophilic Aromatic Substitution, General Corrected Mechanism And Versatile Synthetic Tool
}

\author{
Mieczyslaw Makosza* \\ Institute of Organic Chemistry, Polish Academy of Sciences, Poland
}

Submission: March 03, 2017; Published: March 17, 2017

"Corresponding author: Mieczyslaw Makosza, Institute of Organic Chemistry, Polish Academy of Sciences, ul. Kasprzaka 44/52, 01-224 Warszawa, Poland, Email: icho-s@icho.edu.pl

\section{Mini Reveiw}

Nucleophilic aromatic substitution in electron-deficient arenas, particularly nitroarenes is an efficient tool in synthesis and manufacturing of pharmaceuticals [1-3]. It is therefore of crucial importance to know how exactly these reactions proceed. For many years it was considered that these reactions are limited to substitution of halogens or other nucleofugal groups $\mathrm{X}$ and proceed via addition of nucleophile at positions occupied by $\mathrm{X}$ to form intermediate $\sigma^{\mathrm{X}}$ adducts. Fast departure of X-from these adducts leads to products of $\mathrm{S}_{\mathrm{N}} \mathrm{Ar}$. This addition-elimination mechanism formulated by Bunnet [4] where as a rule the addition is the slow, rate limiting step was subject of thorough studies and refinements and is presented in many reviews, monographs and text-books [5-7] (Scheme 1a).

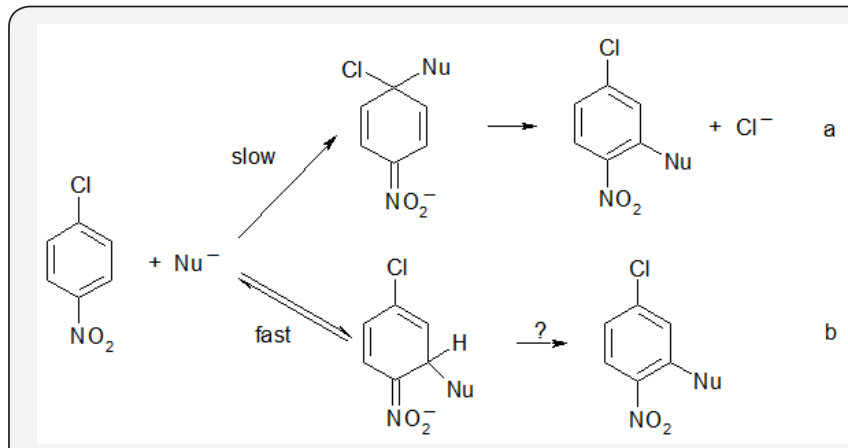

Scheme 1: Addition at positions occupied by halogens is a slow and as a rule irreversible process, whereas addition at positions occupied by hydrogen fast and reversible.

About 30 years ago it become evident that nucleophile can add to nitroarenes, including halonitroarenes, also at positions occupied by hydrogen to form $\sigma^{\mathrm{H}}$ adducts and that this addition mode proceeds faster than the addition at positions occupied by halogen - the first step of the classical $\mathrm{S}_{\mathrm{N}}$ Ar. Since spontaneous departure of hydride anions from the initially formed $\sigma^{\mathrm{H}}$ adducts does not proceed, they usually dissociate so substitution of halogens via slower formation of $\sigma^{\mathrm{X}}$ adducts can proceed (Scheme 1b).

Nevertheless $\sigma^{\mathrm{H}}$ adducts of some nucleophiles under proper conditions can be converted into products of nucleophilic substitution of hydrogen, $\mathrm{S}_{\mathrm{N}} \mathrm{ArH}$ on several ways: oxidation by external oxidants, (oxidative nucleophilic substitution of hydrogen, ONSH) [8, 9], elimination of HL when nucleophile contain a nucleofugal group L, vicarious nucleophilic substitution (VNS), and conversion into substituted nitrosoarenes [10,11]. These reactions are exemplified in Scheme 2.

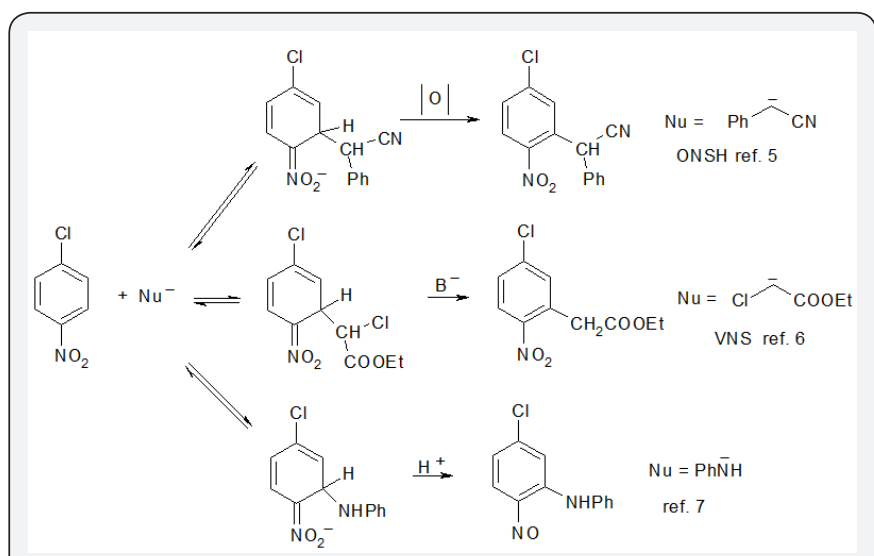

Scheme 2: Three main variants of SNArH in p-chloronitrobenzene proceeds faster than then SNAr of chlorine, so mechanism of this reaction should be corrected.

These results lead to the conclusion that commonly accepted mechanism of $\mathrm{S}_{\mathrm{N}} \mathrm{Ar}$ reaction should be corrected. Indeed on the basis of additional experimental mechanistic studies and ab initio calculations general mechanistic picture of reactions between nucleophile and nitroarenes, that embrace $S_{N} A r$ and $\mathrm{S}_{\mathrm{N}} \mathrm{ArH}$ reactions was formulated $[12,13]$. 


\section{Organic and Medicinal Chemistry International Journal}

Thus, since classical $\mathrm{S}_{\mathrm{N}} \mathrm{Ar}$ of halogens and $\mathrm{S}_{\mathrm{N}} \mathrm{ArH}$ of hydrogen can proceed in the same molecule of a halo nitrobenzene they can be considered as complementary processes. Moreover it is possible that the same reactants (nitroarenes and nucleophile) can react in two or even more different ways depending on the structure and conditions. For instance, carbanion of $\alpha$-phenoxy- and $\alpha$-methoxyphenylacetonitriles can react with o-chloronitrobenzene in five different ways to give five products with high yields and selectivities sic!!! [14]. Scheme 3.

\section{Conclusion}

It is therefore evident that the corrected general mechanism of nucleophilic aromatic opens wide avenue Avenue in organic synthesis particularly valuable for pharmaceutical chemistry. Very useful classical $\mathrm{S}_{\mathrm{N}} \mathrm{Ar}$ of halogens is well known, so it is not necessary to present here examples illustrating its value. On the other hand $\mathrm{S}_{\mathrm{N}} \mathrm{ArH}$ variant of nucleophilic aromatic substitution is much less known hence its versatility and great practical value, as well as some specific features are illustrated by examples presented in Schemes 3-7.

$$
\text { (n) }
$$

Scheme 3: Carbanions of a-alkoxyphenylacetonitriles can react with o-chloronitrobenzenes in five different ways with high selectivity!!!

$$
\begin{aligned}
& \mathrm{X}=\mathrm{Cl}, \mathrm{ArO} \\
& \mathrm{Y}=\mathrm{SO}_{2} \mathrm{Ph}, \mathrm{CN}
\end{aligned}
$$

Scheme 4: VNS reaction is versatile tool for synthesis of indoles.

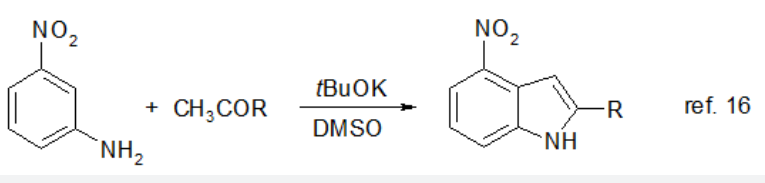

Scheme 5: ONSH is m-nitroanilines by enolate anions open the simplest way of synthesis of 4- or 6-nitroindoles.



It should be stressed that all the presented reactions proceed without using of transition metal catalysts, so are well suited for synthesis of pharmaceuticals. I certainly hope that this text will help chemists practicing organic synthesis to find simple and efficient solutions of their problems.

\section{Reference}

1. Miller J (1969) Aromatic Nucleophilic Substitution. Elsevier, New York, USA, pp: 18.

2. Crampton M R (2016) Chapter 6 in, Arene Chemistry: Reaction Mechanisms and Methods for Aromatic Compounds. Mortier J Ed John Wiley Sons Inc pp: 131-173.

3. Caron S, Ghosh A (2011) Chapter 4 in, Practical Synthetic Organic Chemistry. John Wiley Sons Inc, pp: 237-253.

4. Bunnett J F, Zahler R E (1951) Aromatic Nucleophilic Substitution Reactions. Chem Rev 49(2): 273-412.

5. Terrier F (2013) Modern Nucleophilic Aromatic Substitution. Wiley$\mathrm{VCH}$.

6. Mąkosza M (2011) Nucleophilic Substitution of Hydrogen in Nitroarenes: A New Chapter of Aromatic Chemistry. Synthesis 15: 2341-2356.

7. Makosza M (2010) Nucleophilic substitution of hydrogen in electrondeficient arenes, a general process of great practical value. Chem Soc Rev 39: 2855-2868.

8. Mąkosza M, Kamieńska-Trela K, Paszewski M, Bechcicka M (2005) Oxidative nucleophilic substitution of hydrogen in nitroarenes with phenylacetic acid derivatives. Tetrahedron 61(50): 11952-11964.

9. Sulikowski D, Mąkosza M (2010) Oxidative Nucleophilic Substitution of Hydrogen in Nitroarenes with Carbanions of Protected Serine and Threonine Esters. Eur J Org Chem 22: 4218-4226. 


\section{Organic and Medicinal Chemistry International Journal}

10. Makosza M, Winiarski J (1987) Vicarious nucleophilic substitution of hydrogen. Acc Chem Res 20(8): 282-289.

11. Wróbel Z, Kwast A (2010) Simple Synthesis of N-Aryl-2-nitrosoanilines in the Reaction of Nitroarenes with Aniline Anion Derivatives. Synthesis 22: 3865-3872.

12. Mąkosza M (2014) Reactions of Nucleophiles with Nitroarenes: Multifacial and Versatile Electrophiles. Chem Eur J 20(19): 5536-5545

13. Błaziak K, Danikiewicz W, Mąkosza M (2016) How Does Nucleophilic Aromatic Substitution Really Proceed in Nitroarenes? Computational Prediction and Experimental Verification. J Am Chem Soc 138(23): 7276-7281.

14. Mąkosza M, Sulikowski D (2011) Multiple Reaction Pathways between the Carbanions of $\alpha$-Alkoxy- $\alpha$-phenylacetonitrile and o-Chloronitrobenzene. Eur J Org Chem 34: 6887-6892.

15. Mąkosza M, Wojciechowski K (2004) Nucleophilic Substitution of Hydrogen in Heterocyclic Chemistry. Chem Rev 104(5): 2631-2666.
16. Moskalev N, Barbasiewicz M, Mąkosza M (2004) Synthesis of 4- and 6-substituted nitroindoles Tetrahedron 60(5):347-358.

17. Mąkosza M, Bester K, Cmoch P (2015) One-Pot Synthesis of Esters of Cyclopropane Carboxylic Acids via Tandem Vicarious Nucleophilic Substitution-Michael Addition Process. J Org Chem 80(11): 54365443.

18. Sakowicz A, Loska R, Mąkosza M (2016) One-Pot Synthesis of Oxiranes through Vicarious Nucleophilic Substitution (VNS)-Darzens Reaction. Synlett 27(17): 2443-2446.

19. Mąkosza M, Białecki M (1991) Synthesis of (Nitroaryl)chloromethanes via Vicarious Nucleophilic Substitution of Hydrogen. Synlett 3: 181182.

20. Mąkosza M, Owczarczyk Z (1989) Reactions of organic anions. 161. Dihalomethylation of nitroarenes via vicarious nucleophilic substitution of hydrogen with trihalomethyl carbanions. J Org Chem 54: 5094-5100.

Your next submission with Juniper Publishers
will reach you the below assets
- Quality Editorial service
- Swift Peer Review
- Reprints availability
- E-prints Service
- Manuscript Podcast for convenient understanding
- Global attainment for your research
- Manuscript accessibility in different formats
( Pdf, E-pub, Full Text, Audio)
- Unceasing customer service
Track the below URL for one-step submission
https://juniperpublishers.com/online-submission.php

